\title{
Assessment of a novel pretreatment techniques for enhancing the enzymatic saccharification of sugarcane baggase: Structural and chemical analysis
}

\section{Soni Tiwari}

Banaras Hindu University

Janardan Yadav ( $\sim$ janardanbhu@gmail.com )

Banaras Hindu University https://orcid.org/0000-0002-7867-8941

Rajeeva Gaur

Dr Ram Manohar Lohia Avadh University

Jay Shanker Yadav

Banaras Hindu University

Research

Keywords: Sugar cane bagasse, acid and alkali pretreatment, SEM microscopy, XRD and FTIR spectroscopy

Posted Date: March 9th, 2020

DOI: https://doi.org/10.21203/rs.3.rs-16405/v1

License: (c) (1) This work is licensed under a Creative Commons Attribution 4.0 International License.

Read Full License 


\section{Abstract}

Background Enhancement of cellulase and xylanase production and improvement of more proficient lignocellulose-degrading enzymes are essential in order to decrease the price of enzymes required in the biomass-to-bioethanol production.

Results The effectiveness of different concentration of alkali and acid pretreatment of sugarcane bagasse for improving the enzymatic saccharification of cellulose has been evaluated. The sugarcane bagasse was characterized to contain $39.52 \%$ cellulose, $25.63 \%$ hemicelluloses, $30.36 \%$ lignin, $1.44 \%$ ash and $2.90 \%$ other extractives. Afterthat, The sugarcane bagasse was pretreated with two different concentrations ( $5 \%$ and $10 \%$ ) of $\mathrm{H} 2 \mathrm{SO} 4$ and $\mathrm{NaOH}$ at $121^{\circ} \mathrm{C}$ for $60 \mathrm{~min}$. Among them, the best result was obtained when sugarcane bagasse was pretreated with $10 \% \mathrm{NaOH}$ solution followed by $10 \% \mathrm{H} 2 \mathrm{SO}$ $4,5 \% \mathrm{NaOH}$ and $5 \% \mathrm{H} 2 \mathrm{SO} 4$ solution. The highest cellulose saccharification was $489.5 \mathrm{mg} / \mathrm{g}$ from $10 \%$ $\mathrm{NaOH}$ pretreatment followed by $322.75 \mathrm{mg} / \mathrm{g}, 301.25 \mathrm{mg} / \mathrm{g}$ and $276.6 \mathrm{mg} / \mathrm{g}$ from $10 \% \mathrm{H} 2 \mathrm{SO} 4,5 \%$ $\mathrm{NaOH}$ and 5\% H 2 SO 4 , respectively, which were 55.1, 32.0, 27.1 and 20.6 times higher than the control. Moreover, the FTIR, XRD and SEM analysis showed significant molecule and surface structure changes of the sugarcane bagasse after different pretreatments. Cellulase and xylanase produced by Pseudomonas sp. CVB-10 [MK443365] and Bacillus paramycoides T4 [MN370035] was used to hydrolyze the pretreated sugarcane bagasse and the optimal condition was determined to be $30 \mathrm{~h}$ of enzymatic reaction with 3:1 ration of enzymes under the temperature of $55^{\circ} \mathrm{C}$, pH 5.5 , substrate concentration of $3 \%$ and Tween-20 $0.5 \%$.

Conclusion Enzyme supernatants produced by the mixed culture of Pseudomonas sp. CVB-10 [MK443365] and Bacillus paramycoides T4 [MN370035] on various pretreated sugarcane baggase have good cellulase and xylanase activities, leading to celluloses and Hemicelluloses conversion in the enzymatic hydrolysis/saccharification that is more proficient.

\section{Background}

Sugarcane is one of the most popular crops in India with more than 5 million hectares of land under cultivation. The average yield of sugarcane is more than $75000 \mathrm{~kg} /$ hectare with the total production exceeding 360 million tonnes and 110 million ton of bagasse, a solid waste resulting from juice extraction in 2019. Uttar Pradesh has the largest cultivable land of around 21 lakh hectares. With an annual output of 133.3 million tonnes, Uttar Pradesh stands proudly at the top of the list. The second and third largest states are Maharashtra and Karnataka. Other main sugarcane producing states of India include Bihar, Assam, Haryana, Gujarat, Andhra Pradesh and Tamil Nadu. India hold the second rank in the world after Brazil as far as sugarcane production is concerned.

Sugar industries generated a bulk amount of sugarcane bagasse from sugarcane as a by-product [1], during glucose, xylose, ethanol and methane production as a alternate energy to gasoline has been widely practiced in industry, by virtue of the pronounced fluctuation and increase in oil value, greenhouse 
gas emissions, global warming and big demand of petroleum from some developing countries [2, 3]. A part of sugarcane bagasse was used for electricity production and the remaining 16 million tons of dry bagasse have no direct application. The generation of bioethanol can decrease the import of petroleum and, thereby, increase the autonomy of energy growth in a country (energy security), such as the US and Brazil [4]. Unfortunately, when starchy and sucrose-containing materials are used as feedstocks, it may cause a serious trouble of global food deficiency [5]. Consequently, if bioethanol is generated using lignocellulosic biomass (Sugarcane baggase) as a raw material, not only the crisis of food shortage can be reduced, greenhouse gas emissions due to the utilization of petroleum can also be minimized as well. Sugarcane bagasse is mainly composed of cellulose, hemicellulose and lignin. The predominant component of Sugarcane bagasse biomass is cellulose, a linear $\beta(1,4)$-linked chain of glucose molecules. It is non-toxic, renewable, biodegradable, modifiable and has great potential as an excellent industrial material $[6,7]$. The elementary fibrils are composed of crystalline and amorphous regions.

Hemicelluloses are made up of $\mathrm{C} 5$ and $\mathrm{C} 6$ sugar, such as xylose, arabinose, galactose, glucose and mannose. Lignin accounts for about one fourth of the lignocellulosic biomass and is the third richest biopolymer after cellulose and hemicellulose. According to Fengel and Wegener [8], four elementary fibrils of cellulose are held together by a monolayer of hemicellulose, which make $25 \mathrm{~nm}$ wide thread-like structures that are enclosed in a matrix of hemicelluloses and lignin (associated with each other through physical interactions and covalent bonds).

Various technologies have adopted to improve the bioconversion of these substrates into bioethanol [912]. Enzymatic saccharification is one of the prominent approaches to alter cellulosic biomass into sugars because of low energy constraint and less pollution. Due to the recalcitrant structure of lignocelluloses, a pretreatment step is required prior to enzymatic saccharification in order to make the cellulose more accessible to the enzymes $[13-14,11]$. The main aim of various pretreatment methods is to eliminate the lignin content and to reduce the cellulose crystallinity [15]. Although various physical (comminution, hydro-thermolysis), chemical (acid, alkali, solvents, ozone), and biological pretreatment methods have been examined over the years [16-19].

In acid-catalyzed pretreatment, the major part of the hemicellulose is degraded, and the cellulose has to be hydrolyzed by the use of cellulases. Alkaline pretreatment is basically a delignification process, in which a significant amount of hemicellulose is solubilised as well. The action mechanism is believed to be saponification of Intermolecular ester bonds cross linking xylan hemicelluloses and other components, for example, lignin and other hemicellulose. Alkaline pretreatment also removes acetyl and various uronic acid substitutions on hemicellulose that reduce the accessibility of hemicellulose and cellulose to enzymes [20]. Lignocellulosic materials continue to be investigated as a source of fermentable sugars for biofuel (ethanol) production because of their high availability. In contrast, efficient conversion of lignocellulosic biomass to fermentable sugars is essential for the realization of economic bioethanol [21].

Several characteristics of the solid fraction of pretreated biomass have been studied by many researchers. External morphology (SEM), the main organic groups that constitute the biomass (FTIR) and 
the crystallinity of the cellulose molecule (X-Ray Differaction) have been addressed. Morphological studies with green coconut, soybean straw, wheat bran, rice hulls, sugarcane bagasse and cashew apple have also been carried out after different pretreatments [22-26].

The objective of this work was to apply different pretreatments to sugarcane bagasse and to correlate the chemical composition, crystallinity index, external morphology, and organic groups of the material with the results obtained for glucose production when enzymatic hydrolysis is applied.

\section{Materials And Methods}

\section{Preparation of raw materials}

The raw substrate, sugarcane baggase was collected locally, dried in a hot air oven at $50^{\circ} \mathrm{C}$ and then cut into small pieces. The dried material was ground and passed through a 20-40 mesh size screen using a laboratory knife mill (Metrex Scientific Instrumentation, Delhi, India). The processed substrate was thoroughly washed, dried at $60^{\circ} \mathrm{C}$ and stored in sealed plastic bags at room temperature for further experiments.

\section{Microorganism}

The strain of Pseudomonas sp. CVB-10 and Bacillus paramycoides T4, isolated from soil sample of different sites of Varanasi, was used in this study. The Pseudomonas sp. CVB-10 and Bacillus paramycoides $\mathrm{T} 4$ culture was maintained on $\mathrm{CMC}$ and xylan agar slants at $4^{\circ} \mathrm{C}$ and subcultured monthly.

\section{Inoculum preparation}

Mother culture was prepared by inoculating one full loop of $24 \mathrm{~h}$ grown culture of Pseudomonas sp. CVB10 [MK443365] and Bacillus paramycoides T4 [MN370035] on CMC and xylan agar plate in $50 \mathrm{ml}$ CMC broth and xylan broth, and incubated at $40^{\circ} \mathrm{C}$ for overnight to achieve active exponential phase. Suitable amount of cell suspension were used to inoculate the test flasks.

\section{Enzyme Production}

The culture were grown in a $150 \mathrm{ml}$ Erlenmeyer flask that contain $50 \mathrm{ml}$ of basal medium containing $2.0 \%$ un-treated sugarcane bagasse and $0.5 \%$ ammonium sulphate for cellulase production and $1 \%$ birch wood xylan and $0.05 \%$ ammonium sulphate for xylanase production. The $\mathrm{pH}$ of the medium was adjusted to 5.5 prior to sterilization. The flasks were inoculated and incubated at $40^{\circ} \mathrm{C}$ for $48 \mathrm{~h}$. The crude enzyme was filtered and centrifuged at $10000 \mathrm{rpm}$ for $10 \mathrm{~min}$ and enzyme assay was carried out. Cellulase activity was measured by Nelson-Somogyi method (Nelson, 1944; Somogyi, 1952). One unit of enzyme activity is defined as $1 \mathrm{mg}$ of reducing end group (glucose) released per min at $40^{\circ} \mathrm{C}$.

\section{Sugarcane Bagasse Composition}


Cellulose, hemicellulose, lignin, ash, organic solvent extractives, and hot water extractives $\left(100{ }^{\circ} \mathrm{C}\right)$ contents were quantified in the raw material and in the solid fraction of the pretreated bagasse. The amounts of cellulose, hemicellulose, lignin and ashes were determined according to the methods described by Gouveia et al., [29]. Determinations of organic solvent and hot water extractives were carried out according to the NREL procedure (National Renewable Energy Laboratory, Golden, Colorado -USA) [30] with some modifications; quantification of hot water extractives (sugars, HMF, furfural and organics acids) was carried out by HPLC. All characterizations were assayed in triplicate.

\section{Pretreatments}

\section{Acid pretreatment}

The dilute sulfuric acid ( $98 \%$ purity) pretreatment of Sugarcane baggase substrate $(10.0 \mathrm{~g})$ was carried out using varied acid concentration ( 5 and $10 \%, \mathrm{w} / \mathrm{v}$ ) and incubation time ( 30 and $60 \mathrm{~min}$ ) at $121^{\circ} \mathrm{C}$, using a ratio of $1 / 10$ between the bagasse mass and the volume of acid solution. The hydrolysates after treatment were separated by filtering the contents through double layered muslin cloth. The residual biomass (cellulignin) was washed with tap water till neutral $\mathrm{pH}$ and dried in a hot air oven at $65^{\circ} \mathrm{C}$.

\section{Alkali pretreatment}

The sugarcane baggase $(10.0 \mathrm{~g})$ was presoaked in two different concentrations of alkali $(\mathrm{NaOH})$ ranging from $5 \%$ and $10 \%(\mathrm{w} / \mathrm{v})$ for $2 \mathrm{~h}$ and thereafter thermally pretreated at $121^{\circ} \mathrm{C}$, using a ratio of $1 / 10$ between the bagasse mass and the volume of acid solution for 30 and $60 \mathrm{~min}$. The pretreated sugarcane baggase was filtered through double layered muslin cloth, washed extensively with tap water until neutral $\mathrm{pH}$ and dried at $65^{\circ} \mathrm{C}$.

\section{Structural characterization}

\section{Fourier transform infrared spectroscopy (FTIR) analysis}

The chemical structures of untreated and pretreated sugarcane baggases were characterized by Fourier transform infrared (FTIR) spectrometry (Thermo electron scientific instruments LLC, USA). In addition, FTIR analysis was performed on both the original feedstock before pretreatment and pretreated solid residue after acid and alkali hydrolysis. All solid samples were dried and then pressed into a disc with $\mathrm{KBr}$. The samples ( $\mathrm{KBr}$ pellets) for analyses were prepared by mixing $2 \mathrm{mg}$ material powder with $200 \mathrm{mg}$ $\mathrm{KBr}$. The discs used in this work were thin enough to obey the Beer-Lambert law. Infrared spectra were obtained using a Nicolet iS5 FTIR spectrometer with thirty two scans alongwith resolution of $4 \mathrm{~cm}^{-1}$ in the range of $400 \mathrm{~cm}^{-1}$ and $4000 \mathrm{~cm}^{-1}$. Thus, it was possible to detect the changes caused by the pretreatments in relation to the content of lignin and hemicellulose.

\section{X-ray diffraction (XRD)}


The crystalline nature of native, dilute sulfuric acid treated, dilute sodium hydroxide pretreated, and enzyme digested SB samples was analyzed by using a Rigaku Smart Lab 9kW Powder type (without Xcradle) HR-XRD using monochromatic CuKa radiation (1.54 $\AA$ ) set at $40 \mathrm{KV}, 30 \mathrm{~mA}$. The goniometer scanned a $2 \theta$ range between $5^{\circ}$ and $70^{\circ}$ at a $5^{\circ} / \mathrm{min}$ scanning rate. Samples were scanned over the range of $100<2 \theta<500$ with a step size of $0.05^{\circ}$ and the Crl was determined using the empirical method proposed by Segal et al., [31]. Samples were measured in duplicates and the average values of the $\mathrm{Crl}$ was obtained from the relationship between the intensity of the 002 peak for cellulose I $\left(\mathrm{I}_{002}\right)$ and the minimum dip $\left(l_{a m}\right)$ between the 002 and the 101 peaks, following the formula:

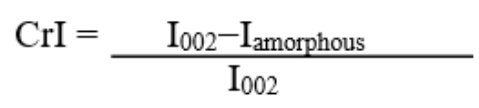

In which, 1002 is the intensity for crystalline portion of biomass at about $2 \mathrm{~h}=22.5$ and $\mathrm{l}_{\mathrm{am}}$ is the peak for the amorphous portion (i.e., cellulose, hemicelluloses and lignin) at about $2 h=16.6$. The second highest peak after $2 h=22.5$ was $2 h=16.6$, and was assumed to correspond to amorphous region [32].

\section{Scanning electron microscopy}

Scanning electron microscopy (SEM) was used to observe the morphology of the raw and pretreated bagasse to evaluate the changes in the external structure caused by the pretreatments (EVO 18 Research ZEISS, UK). SEM was carried out using a voltage of $10 \mathrm{kV}$ and working distance of $10 \mathrm{~mm}$, spot size of 4.0, SE detector and metallizer (EVO 18 Research ZEISS, UK). Before the determination, samples were mounted with conductive glue and coated with a thin layer of gold to improve the conductivity and the quality of the SEM images. Finally, many spots (at least five) were considered for each sample under different magnifications.

\section{Enzymatic saccharification}

The pretreated sugarcane baggase samples were hydrolyzed using condensed enzyme. The hydrolysis reaction was performed in $0.1 \mathrm{M}$ citrate buffer $(\mathrm{pH} 5.0)$ at $50^{\circ} \mathrm{C}$ for $96 \mathrm{~h}$ with shaking $(150 \mathrm{rpm})$. The substrate with buffer was pre-incubated at $50^{\circ} \mathrm{C}$ on a orbit shaker incubator (RC5100 SELEC, NEOLAB, orbit shaker incubator, Germany) at $150 \mathrm{rpm}$ for $2 \mathrm{~h}$ and thereafter the slurry was added with cellulases and xylanases enzymes produced by isolated bacterial culture Pseudomonas sp. CVB-10 and Bacillus paramycoides T4. Tween $20(0.1 \%(\mathrm{v} / \mathrm{v}))$ was also added to the reaction mixture and the reaction continued up to $48 \mathrm{~h}$. Samples of enzymatic hydrolysate were withdrawn at regular intervals and analyzed for amount of glucose released by Nelson and Somogi, [27-28] methods. The effects of different factors e.g., pretreatment reaction time (6-48 h), substrate concentration (1-10\% w/v), temperature $\left(40-60^{\circ} \mathrm{C}\right), \mathrm{pH}(4.0-6.0)$, substrate enzyme ratio $(1: 1,1: 2,1: 3,2: 1,3: 1)$ and Tween-20 concentration (0.1-1.0\%) on the enzymatic hydrolysis was determined by maintaining the enzyme/substrate ratio at $25 \mathrm{FPU} / \mathrm{g}$. All enzyme saccharification experiments were performed in triplicates. 


\section{Statistical analysis}

All the experiments were performed in triplicate and the results are presented as mean \pm standard deviation.

\section{Results And Discussion}

\section{Chemical analysis}

Indigenous sugarcane baggase was applied for chemical composition analysis and found that baggase contain cellulose (39.52\%), hemicellulose (25.63\%), total lignin (30.36\%), ash (1.44\%), and extractives (2.90\%) (Table 1). Similar results were reported by several other workers [17, 33-34]. The composition of sugarcane baggase fluctuates with variety, origin, cultivation type of sugarcane, and the analytical method used for the characterization [35, 17]. In contrast to our result, Moretti et al., [36] observed $46.9 \%$ cellulose, $16.3 \%$ hemicellulose, $27.1 \%$ lignin, and $2.0 \%$ ash in sugarcane baggase. Lamounier et al., [37] observed $54.4 \%$ cellulose, $13.5 \%$ hemicellulose, $26.1 \%$ total lignin, and $0.6 \%$ ash in sugarcane baggase.

Table 1

Compositional analyses of the raw, acid and alkali pretreated sugarcane bagasse

(SCB)

\begin{tabular}{|lllll|}
\hline \multirow{2}{*}{ S.N. } & Components & \multicolumn{2}{l|}{ Composition of sugarcane bagasse biomass (\%) } \\
\cline { 3 - 5 } & & Raw & Acid Treated & Alkali Treated \\
\hline 1 & Cellulose & $39.52 \pm 0.66$ & $45.30 \pm 0.45$ & $52.4 \pm 0.21$ \\
\hline 2 & Hemicellulose & $25.63 \pm 0.44$ & $14.50 \pm 0.37$ & $26.3 \pm 0.19$ \\
\hline 3 & Acid insoluble lignin & $26.40 \pm 0.02$ & $27.70 \pm 0.50$ & $10.9 \pm 0.30$ \\
\hline 4 & Acid soluble lignin & $3.60 \pm 0.90$ & $4.10 \pm 0.61$ & $7.0 \pm 0.50$ \\
\hline 5 & Total Lignin & $30.36 \pm 0.13$ & $31.50 \pm 0.33$ & $17.1 \pm 0.37$ \\
\hline 6 & Organic solvent extract & $1.72 \pm 0.16$ & $1.28 \pm 0.23$ & $0.91 \pm 0.36$ \\
\hline 7 & Hot water extract & $1.32 \pm 0.17$ & $7.52 \pm 0.34$ & $5.97 \pm 0.17$ \\
\hline 8 & Ash & $1.45 \pm 0.21$ & $1.50 \pm 0.21$ & $1.0 \pm 0.29$ \\
\hline 9 & Total & 100.00 & 101.40 & 103.68 \\
\hline The amounts of cellulose, hemicellulose, lignin, and ash are based on dry weight
\end{tabular}

The compositional analysis of the un-treated and the pretreated sugarcane bagasse samples showed that after alkaline pretreatment the proportion of cellulose and hemicellulose increased by 33 and $27 \%$, respectively, while lignin decreased by $44 \%$. Lamounier et al., [37] also reported that after alkali 
pretreatment, lignin content of sugarcane bagasse was decreased by $43 \%$. These results were previously predictable, because alkali works primarily on lignin, promoting its degradation. Lignin is considered a barrier that confines the access of essential enzymes for saccharification [38, 33]. Hence, degradation of lignin may assist the action of cellulases and hemicellulases enymes on cellulose and hemicellulose, respectively. Hydrolysis of hemicellulose and cellulose in alkaline pretreatment is less when compared with acid treated samples $[39,37]$.

Acid pretreatment supported an increase of $14.6 \%$ in cellulose content, an insignificant increase (3.75\%) in the amount of lignin, and the hemicellulose content was decreased by $43.4 \%$. Similarly, Ladeira-Ázar et al., [33] also reported that acid pretreatment enhances cellulose content (26\%) with little increment in lignin, and decreases hemicelluloses content upto $42 \%$. The highest increase in cellulose content was observed after alkali pretreatment, about 33\%. Both acid and alkali pretreatment methods hydrolyzed the majority part of hemicellulose and these results could improve enzyme accessibility to cellulose $[40,37]$.

From the above results it clear that, observed data are in agreement with text which reports that alkaline pretreatment preferentially removes lignin [41,37], and acid pretreatment degrades hemicellulose fraction $[42-43,33]$. Though, the pretreatment process is necessary for enzymatic competence during saccharification process.

\section{Structural characterization}

\section{Fourier transforms infrared (FTIR) spectroscopy}

The chemical structure of untreated and pretreated sugarcane bagasse samples was analyzed by using FTIR. As shown in Figure 1, the spectra generated for samples pretreated by acid ( $5 \%$ and $10 \% \mathrm{H}_{2} \mathrm{SO}_{4}$ at $121^{\circ} \mathrm{C}$ for $60 \mathrm{~min}$ ) and alkali (5\% and $10 \% \mathrm{NaOH}$ at $121^{\circ} \mathrm{C}$ for $60 \mathrm{~min}$ ) were different to that of the untreated sugarcane bagasse; however, there were some major differences observed. For instance, at 897 $\mathrm{cm}^{-1}$, the peak obtained was more intense in cases of acid pretreated sugarcane bagasse compared with untreated and alkali-pretreated sugarcane bagasse. In the presence of amorphous cellulose, the band at $897 \mathrm{~cm}^{-1}$, which characterizes the $\mathrm{C}-0-\mathrm{C}$ stretching at $\beta-1,4-$ glycosidic linkage, is strong and sharp [44$45,17]$. The intensity of the regenerated cellulose band is relatively stronger than that of the original cellulose. It has been reported that the intensity of this peak increases with a decrease in the crystallinity of the cellulose sample and a change in the crystal lattice from cellulose I to cellulose II [27]. These observations indicated that the regenerated cellulose has lower crystallinity, and the pretreatment led to the conversion of the crystalline structure of the original cellulose from cellulose I to cellulose II. The intensity of absorption band in the region $800-950 \mathrm{~cm}^{-1}$ remains unchanged, signifying that both the sugarcane bagasse pretreated and untreated sugarcane do not vary very much in terms of amorphousity.

The absorbencies of 1053 to $1060 \mathrm{~cm}^{-1}$ indicate the disrupted crystalline region for raw and pretreated sugarcane bagasse samples. These bands illustrate the shattering of $\mathrm{H}$-bond in pretreated samples [46, 18]. The band at $1250-1263 \mathrm{~cm}^{-1}(\mathrm{C}-\mathrm{C})$ was more intense in the acid pretreated (5\% and $10 \% \mathrm{H}_{2} \mathrm{SO}_{4}$ at $121^{\circ} \mathrm{C}$ for $60 \mathrm{~min}$ ) and un-treated sugarcane bagasse and disappear in alkali pretreated (5\% and $10 \%$ 
$\mathrm{NaOH}$ at $121^{\circ} \mathrm{C}$ for $60 \mathrm{~min}$ ) sugarcane bagasse, the disappearance of this band indicated that lignin was partially or successfully removed after pretreatment [18] while the band at $1202 \mathrm{~cm}^{-1}$ (C-O and C=O stretching) was more intense in the acid pretreatments. Guilherme et al., [47] also reported similar observation regarding those peaks after sugarcane bagasse pretreatment.

In addition, the broad band at $1375 \mathrm{~cm}^{-1}$ due to phenolic hydroxyl group [48-49]. The mean value for the relative absorbance of phenolic hydroxyl groups was reduced for pretreated bagasse [49]. The peaks at $1,375,1,162$, and $1,055 \mathrm{~cm}^{-1}$ are specifically attributed to $\mathrm{C}-\mathrm{H}$ bending vibration, $\mathrm{C}-\mathrm{O}-\mathrm{C}$ asymmetric bridge stretching vibration and $\mathrm{C}-\mathrm{O}$ stretching vibration in cellulose and hemicellulose, respectively [48, 50-52]. These peaks were weaker for acid and alkali pretreated samples compared to the untreated sample.

The peak at 1,425 $\mathrm{cm}^{-1}$ can be assigned to bending vibration of $\mathrm{CH}_{2}$ [53-54]. This band is strong in crystalline cellulose and weak in amorphous cellulose [55]. So, the crystalline cellulose in treated samples by $\mathrm{H}_{2} \mathrm{SO}_{4}$ (5 and $10 \%$ at $121^{\circ} \mathrm{C}$ for $60 \mathrm{~min}$ ) and $\mathrm{NaOH}\left(5 \%\right.$ at $121^{\circ} \mathrm{C}$ for $60 \mathrm{~min}$ ) and untreated sugarcane bagasse is more than the samples treated by alkali $\left(10 \% \mathrm{NaOH}\right.$ at $121^{\circ} \mathrm{C}$ for $\left.60 \mathrm{~min}\right)$. The results obtained indicate that untreated sugarcane bagasse contained higher amount of crystalline cellulose. On the other hand, cellulose in sugarcane bagasse became more amorphous after pretreatment using strong alkali treatment. It could be concluded that the amount of amorphous cellulose was highest in the sugarcane bagasse sample pretreated by $10 \% \mathrm{NaOH}$ followed by $5 \%, 10 \% \mathrm{H}_{2} \mathrm{SO}_{4}$ and $5 \% \mathrm{NaOH}$, respectively.

The peaks at $1,324,1,514$ and $1604 \mathrm{~cm}^{-1}$ were indicators of hemicelluloses and lignin characteristic [ 54 , 56]. More specifically, $1,324 \mathrm{~cm}^{-1}$ peak reveals the aromatic hydroxyl groups generated by the cleavage of ether bonds within lignin, $1,514 \mathrm{~cm}^{-1}$ is associated with the aromatic skeletal modes of lignin whereas $1,604 \mathrm{~cm}^{-1}$ is stated to be stretching of the $C=C$ and $C=0$ lignin aromatic ring $[57-58,17,56,48]$. As observed in Figure 1, sugarcane bagasse samples subjected to acid pretreatment were delignified slightly for the peaks generated at 1,324, 1,514 and $1604 \mathrm{~cm}^{-1}$ were identical and that there was a subtle difference between the acid pretreated samples and the untreated one. However, peak disappear at 1,324, 1,514 and $1604 \mathrm{~cm}^{-1}$ when sugarcane bagasse subjected to alkali pretreatment was delignified more efficiently in comparison with the acid pretreatments and un-treated sugarcane bagasse. Chandel et al., [177] and Zhang et al., [48] also reported similar results for sugarcane baggasse.

The FTIR analysis of bagasse further showed an aldehyde group absorption peak was clearly present at $1733 \mathrm{~cm}^{-1}$. This absorbance has been suggested to be due to acetyl groups in the lignin or hemicellulose structure [50]. It was observed that, the absorption peak at $1733 \mathrm{~cm}^{-1}$ was disappearance when the sugarcane bagasse treated with acid and alkali pretreatment. The relative absorbance of these two kinds of $\mathrm{CO}$ groups was reduced in the pretreated solid residues [17]. This reduction in the ketone and aldehyde groups may be due to degradation of the aliphatic chain of phenyl propane units in the lignin molecules. The absorbance by hydroxyl groups occurs in as a number of different bands. 
The band at $3395 \mathrm{~cm}^{-1}(\mathrm{O}-\mathrm{H})$ was more intense in the acid pretreatment $\left(5 \%\right.$ and $10 \% \mathrm{H}_{2} \mathrm{SO}_{4}$ at $121^{\circ} \mathrm{C}$ for $60 \mathrm{~min}$ ) than in the alkaline pretreatment $\left(5 \%\right.$ and $10 \% \mathrm{NaOH}$ at $121^{\circ} \mathrm{C}$ for $\left.60 \mathrm{~min}\right)$ and in raw sugarcane bagasse. A similarity in the bands at $2917 \mathrm{~cm}^{-1}$ could be observed for the raw material, acid and the alkaline pretreatment, but was more intense for the acid pretreatments. The $2917 \mathrm{~cm}^{-1}$ band represents $\mathrm{C}-\mathrm{H}$ and $\mathrm{CH}_{2}$ stretching, which is unaffected by changes in crystallinity [27]. The results indicated that the highly crystalline cellulose in sugarcane cane bagasse was transformed to amorphous form after pretreatment. Overall as could be concluded from Figure 2, using alkali pretreatments is a suitable method for removing lignin.

\section{$X-R A Y$ Diffraction}

Figure 2 and Table 2 show the results of the X-ray diffraction analysis carried out to evaluate the crystallinity degree of the raw and pretreated bagasse. The X-ray diffraction (XRD) analysis of untreated sugarcane bagasse, acid ( $5 \%$ and $10 \% \mathrm{H}_{2} \mathrm{SO}_{4}$ at $121^{\circ} \mathrm{C}$ for $60 \mathrm{~min}$ ) pretreated bagasse (cellulignin), and alkali ( $5 \%$ and $10 \% \mathrm{NaOH}$ at $121^{\circ} \mathrm{C}$ for $60 \mathrm{~min}$ ) pretreated cellulignin substrate is presented in Figure 2a-e. The crystallinity index (Crl) of all five samples was calculated by Segal et al., [59] method. Crystallinity is strongly influenced by the biomass composition. The in tensities (1002) of the amorphous cellulose peak and crystalline cellulose peak were considered to calculate the $\mathrm{Crl}$ of all five samples of sugarcane bagasse. The $\mathrm{Crl}$ of untreated sugarcane bagasse was $49.67 \%$, which was close to a previously available report $[60,56]$. The $\mathrm{Crl}$ of acid and alkali pretreated sugarcane bagasse was comparatively lower than untreated sugarcane bagasse showing the sequential increment in cellulose content in these samples (Figure $3 b, c, d, e)$. Acid pretreatment of bagasse ( $5 \%$ and $10 \% \mathrm{H}_{2} \mathrm{SO}_{4}$ at $121^{\circ} \mathrm{C}$ for $60 \mathrm{~min}$ ) removed the hemicellulose, and thus increased the cellulose amount in samples eventually and showed lower $\mathrm{Crl}$ (35.7 and $33.97 \%)$. Further, cellulignin when pretreated with alkali pretreatment $\left(5 \%\right.$ and $10 \% \mathrm{NaOH}$ at $121^{\circ} \mathrm{C}$ for $60 \mathrm{~min}$ ) showed lower $\mathrm{Crl}(41.1$ and $11.2 \%$ ) because of the removal of lignin, and thus increased the cellulose concentration in bagasse than that of untreated sugarcane bagasse and cellulignin. This $\mathrm{Crl}$ value was the least when compared with those achieved through the application of the other pretreatment process. In other words, this sharp decrease in crystallinity due to the alkali pretreatment confirms that the regenerated products were highly amorphous and thus, cellulose surface accessibility and consequently the efficiency of enzymatic hydrolysis were considerably increased $[50,56]$. The fragmentation of the lignocellulosic structure of bagasse (Figure $2 \mathrm{~b}-\mathrm{e}$ ) may also cover the $\beta$-glycosidic bonds of cellulose, resulting in the disappearance of the band [56]. Different pretreatment methods can alter cellulose crystal structures by disrupting inter- and intra-chain hydrogen bonding of cellulose fibrils $[15,54]$. The lower crystallinity index indicates a higher amount of amorphous cellulose present in the regenerated cellulose $[61,47,56]$. Reports suggested that anion and cation in acid and alkali are responsible for the dissolution and disruption of cellulose [62-64, 50]. It was indicated that the anion in alkali attacked the free hydroxyl group on cellulose and deprotonated it, while the cation interacted with the hydroxyl oxygen atoms. The hydrogen bonds in cellulose were disrupted and replaced by hydrogen bonding between the anion of alkali and cellulose hydroxyls [18]. Consequently, cellulose dissolution occurred and the crystalline structure was disrupted. Li et al., [65] and Uju et al., [66] also suggested that 
the decrease of Crl, probably due to the rapid precipitation with water, prevented the dissolved lignocellulosic material from restructuring into its original crystalline structure, which resulted in a fragmented and porous biomass with amorphous structure and greater surface area for enzymes to attach.

\section{Table 2: Crystallinity index of un-treated, acid and alkali pretreated sugarcane bagasse}

\begin{tabular}{|lll|}
\hline S.N. & Pretreatment & Crytallinity Index (\%) \\
\hline 1 & Un-treated sugarcane bagasse & 49.67 \\
\hline 2 & $5 \%$ Sulphuric acid treated sugarcane bagasse at $121^{\circ} \mathrm{C}$ for 60 min & 35.7 \\
\hline 3 & $\begin{array}{l}10 \% \text { Sulphuric acid treated sugarcane bagasse at } 121^{\circ} \mathrm{C} \text { for } 60 \text { min } \\
4\end{array}$ & 33.97 \\
\hline 5 & $\begin{array}{l}10 \% \text { Sodium hydroxide treated sugarcane bagasse at } 121^{\circ} \mathrm{C} \text { for } 60 \text { min } \\
\text { min }\end{array}$ & 41.1 \\
\hline
\end{tabular}

During the autoclave conditions, the splitting rate of $\mathrm{NaOH}$ was significantly increased and eventually the crystalline structure was converted to the amorphous state. In addition, the aqueous $\mathrm{NaOH}$ solution acts as an intra-crystalline swelling agent that can penetrate and swell both the accessible amorphous and crystalline region. Hence, destruction of cellulose crystalline structure occurred and fibril sequences in cellulose were distorted. As a result, microfibrils loomed out from the connected structure and become fully exposed, thus heightening the external surface and porosity of the cellulose.

\section{Scanning electron microscopy}

Figure 3 presents the morphological structural changes obtained in sugarcane bagasse during the acid (5 and $10 \% \mathrm{H}_{2} \mathrm{SO}_{4}$ at $121^{\circ} \mathrm{C}$ for $60 \mathrm{~min}$ ) and alkaline (5 and $10 \% \mathrm{NaOH}$ at $121^{\circ} \mathrm{C}$ for $60 \mathrm{~min}$ ) pretreatment. Scanning electron microscopy images of un-treated, acid and alkali pretreated sugarcane bagasse samples were taken at different magnifications. Figure (3a) clearly indicates that the untreated sugarcane bagasse had highly compact, ordered and rigid fibril morphology [45] when compare with acid and alkali pretreated bagasse samples (Figure 3b-e). Several workers have been reported similar observation for untreated and treated sugarcane bagasse $[60,56]$.

Sugarcane bagasse residue from alkali-pretreatment $\left(10 \% \mathrm{NaOH}\right.$ at $121^{\circ} \mathrm{C}$ for $\left.60 \mathrm{~min}\right)$ was the most severely disrupted followed by $5 \% \mathrm{NaOH}$ alkali, $10 \% \mathrm{H}_{2} \mathrm{SO}_{4}$ and $5 \% \mathrm{H}_{2} \mathrm{SO}_{4}$ acid-pretreatments. The disruption of the residue surface might have been caused by the solvating action of the acid and alkali pretreatment, in which the outer lignocellulosic matrix of sugarcane bagasse was swelled and dissolved in the acid and alkali pretreatments [61]. Due to the partial removal of hemicelluloses and lignin, the surface of the sugarcane bagasse with $\mathrm{NaOH}$ pretreatment became soft, loosened, and contained some micro-pores on the surface of the sugarcane bagasse (Figure $3 \mathrm{~d}$ and e). From the figure it revealed that 
surface has become rough, puffy, loose and conglomerate textures and the native fibrous structure has been wholly distorted after the pretreatment by $10 \% \mathrm{NaOH}$ at $121^{\circ} \mathrm{C}$ for $60 \mathrm{~min}$. In other words, the fibrous structure of the sugarcane bagasse has been changed into a spongy and amorphous form after the alkali pretreatment. This also indirectly indicates that, with acid and alkali pretreatment, crystallinity of the cellulose could be reduced compared to the untreated sugarcane bagasse $[17,47,45]$. Acid (5\% and $10 \%$ $\mathrm{H}_{2} \mathrm{SO}_{4}$ at $121^{\circ} \mathrm{C}$ for $\left.60 \mathrm{~min}\right)$ and alkali $\left(5 \% \mathrm{NaOH}\right.$ at $121^{\circ} \mathrm{C}$ for $\left.60 \mathrm{~min}\right)$ pretreatments had similar effects on sugarcane bagasse (Figure $3 \mathrm{~b}-\mathrm{e}$ ) and led to highest modifications in sugarcane bagasse structure after $10 \%$ alkali pretreatment. Similarly, Fasanella et al., [19] also reported that when bagasse treated with $\mathrm{NaOH}$, it not only break the lignin structure, but also hydrate and swell the cellulose fibers, reducing crystallinity. Accessibility of the substrate to the cellulolytic enzymes is one of the major factors influencing the hydrolysis process $[55,67,56]$. Previous study has illustrated that the cellulases can get trapped in the pores if the internal area is much larger than the external area [68-69]. Thus, one of the objectives of the pretreatment is to increase the porosity and available surface area for the enzymatic attack $[70,56,45]$. The morphological investigation in the present study showed a significant increase in the porosity and surface area after the pretreatment, thus contribute to the enhancement of subsequent enzymatic hydrolysis $[49,56,45]$.

\section{Enzymatic hydrolysis}

Enzymatic hydrolysis of pretreated sugarcane bagasse was carried out by using cellulase and xylanase filtrate of Pseudomonas sp. CVB-10 and Bacillus paramycoides T4. Five different type processed sugarcane bagasse (Un-treated sugarcane bagasse, $5 \%$ \& $10 \% \mathrm{NaOH}$ at $121^{\circ} \mathrm{C}$ for 60 min and $5 \%$ \& $10 \%$ $\mathrm{HCl}$ at $121^{\circ} \mathrm{C}$ for $60 \mathrm{~min}$ treated sugarcane bagasse) were used for enzymatic saccharification. The various parameters such as hydrolysis time, substrate concentration, temperature, $\mathrm{pH}$, enzyme ratio and different concentration of tween-20 were optimized to achieve maximum saccharification of sugarcane bagasse. All data is graphically represented in (Figure 4a-f). A maximum of $489.50 \mathrm{mg} / \mathrm{g}$ glucose was obtained from the base pretreated SB after 30 hours of enzymatic hydrolysis. Acid pretreated bagasse (cellulignin) showed only $322.75 \mathrm{~g} / \mathrm{I}$ sugars recovery proving the requirement of alkali mediated delignification. Chandel et al., [17] also reported that alkali pre-treated substrate showed maximum saccharification and reducing sugar production.

\section{The effect of time on the enzymatic hydrolysis}

In this experiment, we determined the effect of enzymatic reaction time on saccharification/hydrolysis of the un-treated and pretreated sugarcane bagasse. All un-treated and pretreated sugarcane bagasse samples were mixed with filtrate cellulase and xylanase for 6-48 $\mathrm{h}$ and the concentration of released reducing sugar was measured every $6 \mathrm{~h}$ interval. From result it clear that, the concentration of the released reducing sugars was increased, as the reaction time was increased (Figure 4a). A maximum of $430.95 \mathrm{mg} / \mathrm{g}$ reducing sugars with a maximal saccharification was obtained from $10 \% \mathrm{NaOH}$ at $121^{\circ} \mathrm{C}$ followed by $10 \% \mathrm{H}_{2} \mathrm{SO}_{4}(309.9 \mathrm{mg} / \mathrm{g}), 5 \% \mathrm{NaOH}(289.6 \mathrm{mg} / \mathrm{g}) \& 5 \% \mathrm{H}_{2} \mathrm{SO}_{4}(250.67 \mathrm{mg} / \mathrm{g})$ at $121^{\circ} \mathrm{C} 30 \mathrm{~h}$ 
of enzymatic hydrolysis. The content of reducing sugar was gradually decreased after $30 \mathrm{~h}$ of incubation. This might be due to the inhibition of the enzyme activity by the accumulated hydrolysis products.

\section{The effect of substrate concentration on the enzymatic hydrolysis}

The effect of substrate concentration on enzyme saccharification/hydrolysis was determined by using $1.0 \%-8.0 \%$ of un-treated and pretreated sugarcane bagasse under optimized parameters. The results showed that the maximum $450.78 \mathrm{mg} / \mathrm{g}$ reducing sugar with maximum saccharification was achieved at $5 \%$ substrate concentration ( $10 \%$ alkali pretreated sugarcane bagasse) within $30 \mathrm{~h}$ (Figure $4 \mathrm{~b}$ ). Above and below of this substrate concentration, enzymatic saccharfication rate and hydrolysis rate were decreased gradually. Similarly, Gupta et al., [10] also reported that maximum reducing sugar production/saccharification was reported at $5 \%$ substrate concentration. Studies have revealed that as the substrates were increased; the feedback inhibition by cellobiose and glucose was improved, leading to the reduced production of reducing sugars in the enzymatic reaction.

\section{The effect of temperature on the enzymatic hydrolysis}

Temperature is an important factor, which influences not only the enzymatic reaction, but also the activity of the cellulase and xylanase. Generally, as the temperature is raised in a certain range, the enzymatic activity is accelerated. Enzyme catalyzed reaction like most chemical reactions; proceeds at a faster velocity as the temperature is increased. An increase in temperature would impart more kinetic energy to the reactant molecules resulting in more productive collision per unit time $[71,18]$. Although, when the temperature is further raised outside this range, the enzyme becomes deactivated/denatured, leading to inhibit enzymatic turnover number. The optimal reaction temperature for cellulase and xylanase is between $45^{\circ} \mathrm{C}-55^{\circ} \mathrm{C}$. However, the optimal temperature varies for the enzymes from different sources and different enzymatic matrix. This investigation was performed at constant substrate loading, $5 \%(\mathrm{w} / \mathrm{v})$ and enzyme reaction time, $30 \mathrm{~h}$ at $\mathrm{pH}, 5.0$, respectively. In this experiment, maximum reducing sugars (456.87 $\mathrm{mg} / \mathrm{g}$ substrate) with maximum saccharification rate was observed at $55^{\circ} \mathrm{C}$ from alkali pretreated sugarcane baggase (10\%) (Figure 4c). Lamounier et al., [37] also reported that maximum reducing sugar

production during saccharification at $55^{\circ} \mathrm{C}$. Further increased temperature beyond $55^{\circ} \mathrm{C}$, the concentration of reducing sugar and saccharification rate were reduced. An enzyme molecule has a very delicate and fragile structure. If the molecule absorbs too much energy, the tertiary structure will be disrupted and the enzyme will lose its catalytic activity and eventually denature. Thus, the optimal temperature for enzymatic saccharification/hydrolysis was $55^{\circ} \mathrm{C}$. Based on the results the temperature $55 \mathrm{C}$ was chosen for further experiments.

\section{The effect of $\mathrm{pH}$ on the enzymatic hydrolysis}

The enzymatic saccharification/hydrolysis was also affected by their initial pH conditions. The experiments were conducted at constant temperature, $55^{\circ} \mathrm{C}$, enzymatic reaction time, $30 \mathrm{~h}$ and substrate loading, $5 \%(\mathrm{w} / \mathrm{v})$. In this experiment, different $\mathrm{pH}$ ranges (4.0 to 6.0$)$ were applied to attained maximum enzymatic saccharification/hydrolysis at optimum $\mathrm{pH}$. Figure $4 \mathrm{~d}$ depicted that maximum reducing sugars 
( $470.03 \mathrm{mg} / \mathrm{g}$ ) with maximum saccharification were achieved at $\mathrm{pH} 5.0$ from alkali pretreated sugarcane bagasse. When $\mathrm{pH}$ was increased or decreased than 5.0, the enzymatic reaction was reduced [18]. Initial $\mathrm{pH}$ Changes may result in the failure of cellulase and xylanase activity or dissociation may occur between substrate and active site of enzyme, the enzyme-catalyzed hydrolysis reaction to achieve maximal activity of enzyme. Generally, enzymes have ionic groups on their active sites and must be in suitable form either acid or base to function. A change of $\mathrm{pH}$ in the medium would lead to modification of enzyme in the ionic form of active site and its three-dimensional shape $[72,18]$. For these reasons, enzymes are only active over a certain $\mathrm{pH}$ range.

\section{Effect of enzyme ratio}

Enzyme ratio also influences enzymatic saccharification/hydrolysis of pretreated sugarcane bagasse. Figure 4 (e) depicts the different enzyme ratios on the enzymatic saccharification/hydrolysis of all five samples. Different range of enzyme ratio (cellulase: xylanase); 1:1, 1:2, 1:3, 2:1 and 3:1, were used. During the saccharification process, the other optimized parameters such as enzyme incubation time, temperature, $\mathrm{pH}$ and substrate loading were kept constant. The highest amount of reducing sugar 476.9 $\mathrm{mg} / \mathrm{g}$ with maximum saccharification was obtained after $30 \mathrm{~h}$ reaction when enzyme ratio was at 3:1. It was then followed by the enzyme ratio $2: 1,1: 3,1: 2$ and $1: 1$. When the sugarcane bagasse cellulose was degraded by cellulase, the main product formed was glucose and sugarcane also contains a little amount of hemicellulose. The hemicellulose may inhibit enzymatic reaction, resulting in low glucose content. Therefore the addition of extra xylanase amount is desired and would directly increase the glucose yield. The findings illustrated that the enzyme ratio of 2:1 and 3:1 produced higher amounts of reducing sugar compared others. Therefore, based on this result, the enzyme ratio of 3:1 was selected for subsequent experiments. Similarly, Lai and Idris, [18] also reported that 5:1 ratio of cellulase: $\beta$-glucosidase showed maximum glucose production.

\section{Effect of different concentration of tween-20 on the enzymatic hydrolysis}

Surfactant also influences the enzymatic hydrolysis at different concentrations by increasing the surface area of the substrate. In this experiment different concentration (0.1-1.0\%) of tween-20 were optimized for maximum saccharification under all optimized conditions. Figure (4f) depicted that maximum 489.50 $\mathrm{mg} / \mathrm{g}$ reducing sugar with maximum saccharification rate was achieved at $0.5 \%$ tween-20 concentration. Above and below this concentration there is no significant result was reported from the surfactant. Surfactants generally enhance the surface area of lignocellulosic substrates to improve the extent of enzymatic hydrolysis. Non-ionic surfactant-like Tween 20 is more effective due to its adsorption on hydrophobic surfaces mainly composed of lignin fragments $[73,17]$.

\section{Conclusion}

Many factors including the content of lignin, surface areas, crystallinity and degree of polymerization affect the efficiency of substrate hydrolysis by cellulase and xylanase. The purpose of pretreatment is to remove lignin and hemicellulose, reduce cellulose crystallinity and increase the porosity. Therefore, selecting appropriate pretreatment methods plays a significant role in increasing the efficiency of 
cellulose hydrolysis. The pretreatment method used in this study attempts to increase the accessible surface area, decrease the content of lignin and disrupt the polymerization of sugarcane bagasse. Two different concentrations of acid and alkali were applied for pretreatment of sugarcane bagasse. Among different concentration of acid and alkali pretreatments studied, the $10 \% \mathrm{NaOH}$ pretreatment was found to be the most competent in lignin removal and led to the enhancement of the cellulose and hemicellulose content in pretreated sugarcane bagasse. This treatment technique recommends the opportunity of producing cellulosic material largely free from lignin, which ultimately would be a good substrate for bioethanol generation. However, there is a need to build up proficient biological delignification techniques to formulate the process eco-friendly. The FTIR, XRD and SEM analysis showed $10 \% \mathrm{NaOH}$ pretreatment followed by $10 \% \mathrm{H}_{2} \mathrm{SO}_{4}, 5 \% \mathrm{NaOH}$ and $5 \% \mathrm{H}_{2} \mathrm{SO}_{4}$ pretreatment as most efficient in terms of altering the morphology of sugarcane bagasse. Overall, $10 \% \mathrm{NaOH}$-pretreated sugarcane bagasse showed maximum saccharification/hydrolysis $498.5 \mathrm{mg} / \mathrm{g}$ reducing sugar after $30 \mathrm{~h}$, whereas hydrolysis of untreated sugarcane bagasse generated only $219.4 \mathrm{mg} / \mathrm{g}$ reducing sugar.

\section{Declarations}

\section{Ethics approval and consent to participate}

This article does not contain any studies with human participants or animals performed by any of the authors.

\section{Consent for publication}

All authors consent to publish this manuscript.

\section{Availability of data and materials}

Name of the repository is NCBI (National Center for Biotechnology Information) where our data's were deposited and a link to the dataset DOI are https://www.ncbi.nlm.nih.gov/nucleotide/MK443365.1 and https://www.ncbi.nlm.nih.gov/nuccore/MN370035.1. The supporting data also include in this manuscript as a supporting file at the end of manuscript.

\section{Competing interests}

The author(s) declare that they have no competing interests.

\section{Funding}

This work was financially supported by the University Grant Commission Delhi, India [F-42/2006(BSR)/BL/17-18/0049].

\section{Authors' contributions}

1. Soni Tiwari carried out the research work and drafted the manuscript. 
2. Janardan Yadav and Rajeeva Gaur has designed the experiment, contributed substantially to analysis and interpretation of data and have given final approval of the version to be published.

3. Jai Shanker performed the Molecular characterization of the isolates and the data analysis.

All authors read and approved the final manuscript.

\section{Acknowledgement}

Dr. D.S. Kothari PDF Fellow is greatly acknowledged by all Authors.

\section{References}

1. Hofsetz K, Silva MA. Brazilian sugarcane bagasse: Energy and non-energy consumption. Biomass Bioener. 2012; 46: 564-73.

2. Quintero JA, Montoya MI, Sánchez OJ, Giraldo OH, Cardona CA. Fuel ethanol production from sugarcane and corn: comparative analysis for a Colombian case. Energy. 2008; 33: 385-99.

3. Demirbas MF. Biorefineries for biofuel upgrading: a critical review. Appl Ener. 2009; 86: S151-61.

4. Balat $\mathrm{M}, \mathrm{Balat} \mathrm{H}$. Recent trends in global production and utilization of bioethanol fuel. Appl Ener. 2009; 86: 2273-82.

5. Demirbas A. Competitive liquid biofuels from biomass. Appl Ener. 2011; 88: 17-28.

6. Pandey A, Soccol CR, Nigam P, Soccol VT. Biotechnological potential of agro-industrial residues Sugarcane bagasse. Bioresour Technol. 2000; 74:69-80.

7. Richardson S, Gorton L. Characterisation of the substituent distribution in starch and cellulose derivatives. Anal Chim Acta. 2003; 497: 27-65.

8. Fengel D, Wegener G. Wood: chemistry, ultrastructure, reactions. XII. Berlin, New York: Walter de Gruyter 1989.

9. Kapoor RK, Chandel AK, Kuhar S, Gupta R, Kuhad RC. Bioethanol from crop residues, production forecasting and economics: An Indian perspective. In R. C. Kuhad, \& A. Singh (Eds.), Lignocellulose biotechnology: Future prospects (pp. 247-261). New Delhi: IK International 2007.

10. Gupta R, Khasa YP, Kuhad RC. Evaluation of pretreatment methods in improving the enzymatic saccharification of cellulosic materials. Carbohyd Poly. 2011; 84:1103-109.

11. Ko JK, Um Y, Woo HM, Kim KH, Lee S-M. Ethanol production from lignocellulosic hydrolysates using engineered Saccharomyces cerevisiae harboring xylose isomerase-based pathway. Bioresour Technol. 2016; 209: 290-96.

12. Costa CE, Romaní A, Cunha JT, Johansson B, Domingues Integrated approach for selecting efficient Saccharomyces cerevisiae for industrial lignocellulosic fermentations: Importance of yeast chassis linked to process conditions. Bioresour Technol. 2017; 227: 24-34.

13. Galbe M, Zacchi G. A review of the production of ethanol from softwood. Appl Microbiol Biotechnol. 2002; 59: 618-28. 
14. Zhao X, Zhang L, Liu D. Comparative study on chemical pretreatment methods for improving enzymatic digestibility of Crofton weed stem. Bioresour Technol. 2008; 99: 3729-36.

15. Mosier N, Wyman C, Dale B, Elander R, Lee YY, Holtzapple M et al. Features of promising technologies for pretreatment of lignocellulose biomass. Bioresour Technol. 2005; 99: 673-86.

16. Gupta R, Mehta G, Khasa YP, Kuhad RC. Fungal delignification of lignocellulosic biomass improves the saccharification of cellulosics. Biodegra. 2010. doi:10.1007/s10532-010-9404-6.

17. Chandel AK, Antunes FAF, Anjos V, Bell MJV, Rodrigues LN, Polikarpov I, de Azevedo ER, Bernardinelli OD, Rosa CA, Pagnocca FC, da Silva SS. Multi-scale structural and chemical analysis of sugarcane bagasse in the process of sequential acid-base pretreatment and ethanol production by Scheffersomyces shehatae and Saccharomyces cerevisiae. Biotechnol Biofuels. 2014; 7: 63.

18. Lai LW, Idris A. Comparison of steam-alkali-chemical and microwave-alkali pretreatment for enhancing the enzymatic saccharification of oil palm trunk. Renewable Ener. 2016; 99: 738-46.

19. Fasanella CC, Montes CR, Rossi ML, Aguiar MM, Ferreira LFR, Pupo MMS, Salazar-Banda GR, Monteiro R. Microscopic Analysis Of Sugarcane Bagasse Following Chemical And Fungal Treatment. Cellulose Chem Technol. 2018; 52 (1-2): 59-64.

20. Chang V, Burrm B, Holtzapple M. Lime pretreatment of switchgrass. Appl Biochem Biotechnol. 1997; 63-65: 3-19.

21. Sheehan J, Himmel ME. Enzymes, energy, and the environment: Cellulose development in the emerging bioethanol industry. Biotechnol Progress. 1999; 15: 817-827.

22. Xu Z, Wang Q, Jianga ZH, Yang X, Ji Y. Enzymatic hydrolysis of pretreated soybean straw. Biomass Bioener. 2007; 31: 162-67.

23. Brigida AIS, Calado VMA, Gonçalves LRB, Coelho MAZ. Effect of chemical treatments on properties of green coconut fiber. Carbohyd Poly. 2010; 79: 832-38.

24. Rocha MVP. Produção de Bioetanol a partir de Pedúnculo de Caju (Anacardium occidentale L.) por Fermentação Submersa. Ph.D. Thesis, Universidade Federal do Rio Grande do Norte (In Portuguese), 2010.

25. Zhao X, Zhou Y, Zheng G, Liu D. Microwave pretreatment of substrates for cellulase production by solid-state fermentation. Appl Biochem Biotechnol. 2010; 160: 1557-571.

26. Camargo FA, Innocentini-Mei LH, Lemes AP, Moraes SG, Duran N. Processing and characterization of composites of poly(3-hydroxybutyrateco-hydroxyvalerate) and lignin from sugar cane bagasse. $\mathrm{J}$ Composite Mater. 2012; 46: 417-25.

27. Nelson ML, O'Connor RT. Relation of certain infrared bands to cellulose crystallinity and crystal lattice type. Part II. A new infrared ratio for estimation of crystallinity in cellulose I and II. J Appl Poly Sci. 1964; 8: 1325- 341.

28. Somogyi M. Notes on sugar determination. J Biol Chem. 1952; 195:19-23.

29. Gouveia ER, Nascimento RT, Souto-Maior AM, Rocha GJM. Validação de metodologia para a caracterização química de bagaço de canade-açúcar. Quim. Nova, 2009; 32: 1500-503. 
30. Sluiter A, Ruiz R, Scarlata C, Sluiter L, Templeton D. Determination of Extractives in Biomass. Laboratory Analytical Procedure (LAP). Technical Report, NREL, 2008; p. 12.

31. Segal L, Creely JJ, Jr Martin AE, Conrad CM. An empirical method for estimating the degree of crystallinity of native cellulose using the X-ray diffractometer. Textile Res J. 1959; 29: 786-94.

32. Kumar R, Mago G, Balan V, Wyman CE. Physical and chemical characterizations of corn stover and poplar solids resulting from leading pretreatment technologies. Bioresour Technol. 2009; 100: 39483962.

33. Ladeira-Ázar RIS, Morgan T, Maitan-Alfenas GP, Guimarães VM. Inhibitors Compounds on Sugarcane Bagasse Saccharification: Effects of Pretreatment Methods and Alternatives to Decrease Inhibition. Appl Biochem Biotechnol. 2018 https://doi.org/10.1007/s12010-018-2900-6

34. Shi T, Lin J, Li J, Zhang Y, Jiang C, Lv X, Fan Z, Xiao W, Xu Y, Liu Z. Pre-treatment of sugarcane bagasse with aqueous ammonia-glycerol mixtures to enhance enzymatic saccharification and recovery of ammonia. Bioresour Technol. 2019; 289: 1216-1228.

35. Canilha L, ChandelAK, dos Santos Milessi TS, Antunes FAF, da Costa Freitas WL, das Graças Almeida Felipe M, da Silva Bioconversion of Sugarcane Biomass into Ethanol: An Overview about Composition, Pretreatment Methods, Detoxification of Hydrolysates, Enzymatic Saccharification, and Ethanol Fermentation. J Biomed Biotechnol. 2012; 15. http://dx.doi.org/10.1155/2012/989572

36. Moretti MMDS, Bocchini-Martins DA, Nunes CDCC, Vilhena MA, Perrone OM, DaSilva R, Boscolo M,Gomes E . Pretreatment of sugarcane bagasse with microwaves irradiation and its effects on the structure and on enzymatic hydrolysis. Appl Ener. 2014; 122: 189- 95.

37. Lamounier KFR, Rodrigues PO, Pasquini D, Baffi MA. Saccharification of Sugarcane Bagasse Using an Enzymatic Extract Produced by Aspergillus fumigatus. J Renewable Mat. 2018; 6(2):

38. Nakagame S, Chandra RP, Kadla JF, Saddler JN. The isolation, characterization and effect of lignin isolated from steam pretreated Douglas-fir on the enzymatic hydrolysis of cellulose. Bioresour Technol. 2011; 102(6): 4507-517.

39. Carvalheiro F, Duarte LC, Girio FM. Hemicellulose biorefineries: a review on biomass pretreatments. J Scient Indus Res. 2008; 67: 849-64.

40. Maitan-Alfenas GP, Visser EM, Alfenas RF, Nogueira BRG, de Campos GG, Milagres AF, de Vries RP, Guimaraes VM. The influence of pretreatment methods on saccharification of sugarcane bagasse by an enzyme extract from Chrysoporthe cubensis and commercial cocktails: a comparative study. Bioresour Technol. 2015; 192: 670-76.

41. Falkoski DL, Guimaraes VM, de Almeida MN, Alfenas AC, Colodette JL, de Rezende ST. Chrysoporthe cubensis: a new source of cellulases and hemicellulases to application in biomass saccharification processes. Bioresour Technol. 2013; 130: 296-305.

42. Hendriks ATWM, Zeeman G. Pretreatments to enhance the digestibility of lignocellulosic biomass. Bioresour Technol. 2009; 100(1): 10-18.

43. Harrison MD, Zhang Z, Shand K, Hara IMO, Doherty WOS, Dale JL. Effect of pretreatment on saccharification of sugar cane bagasse by complex and simple enzyme mixtures. Bioresour Technol, 
2013; 148: 105-113.

44. Pandey KK, Pitman AJ. FTIR studies of the changes in wood chemistry following decay by brown-rot and white-rot fungi. Inter J Biodetio Biodegra. 2003; 52: 151-60.

45. Zhang H, Huang S, Wei W, Zhang J, Xie Investigation of alkaline hydrogen peroxide pretreatment and Tween 80 to enhance enzymatic hydrolysis of sugarcane bagasse. Biotechnol Biofuels. 2019; 12: 107.

46. Guo G-L, Hsu D-C, Chen W-H, Chen W-H, Hwang W-S. Characterization of enzymatic saccharification for acid-pretreated lignocellulosic materials with different lignin composition. Enzy Micro Technol. 2009; 45: 80-87.

47. Guilherme AA, Dantas PVF, Santos ES, Fernandes FAN, Macedo GR. Evaluation of composition, characterization and enzymatic hydrolysis of pretreated sugar cane bagasse. Braz J Chem Engineer. 2015; 32(1): 23-33.

48. Labbe N, Rials TG, Kelley SS, Cheng ZM, Kim JY, Li Y. FT-IR imaging and pyrolysis-molecular beam mass spectrometry: new tools to investigate wood tissues. Wood Sci Technol. 2005; 39: 61-77.

49. Remli NAM, Md Shah UK, Mohamad R, Abd Aziz S. Effects of chemical and thermal pretreatments on the enzymatic saccharification of rice straw for sugars production. BioResources. 2014; 1: 510-22.

50. Yoon LW, Ngoh GC, Chua ASM, Hashim MA. Comparison of ionic liquid, acid and alkali pretreatments for sugarcane bagasse enzymatic saccharification. J Chem Technol Biotechnol. 2011; 86: 13421348.

51. Karthika K, Arun AB, Melo JS, Mittal KC, Kumar M, Rekha PD. Hydrolysis of acid and alkali presoaked lignocellulosic biomass exposed to electron beam irradiation. Bioresour Technol. 2013; 129: 646-49.

52. Qing Q, Hu R, He Y, Zhang Y, Wang L. Investigation of a novel acid-catalyzed ionic liquid pretreatment method to improve biomass enzymatic hydrolysis conversion. Appl Microbiol Biotechnol. DOI 10.1007/s00253-014-5664-0.

53. Han L, Feng J, Zhang S, Ma Z, Wang Y, Zhang X. Alkali pretreated of wheat straw and its enzymatic hydrolysis. Braz J Microbiol. 2012; 53-61.

54. Mood SH, Golfeshan AH, Tabatabaei M, Abbasalizadeh S, Ardjmand M. Comparison of different ionic liquids pretreatment for barley straw enzymatic saccharification. 3 Biotech. 2013. DOI 10.1007/s13205-013-0157-x.

55. Bian J, Peng F, Peng X-P, Xiao X, Peng P, Xu F, Sun R-C. Effect of [Emim]Ac pretreatment on the structure and enzymatic hydrolysis of sugarcane bagasse cellulose. Carbohyd Poly. 2014;100: 21117.

56. Lv X, Lin J, Luo L, Zhang D, Lei S, Xiao W, Xu Y, Gong Y, Liu Z. Enhanced enzymatic saccharification of sugarcane bagasse pretreated by sodium methoxide with glycerol. Bioresour Technol. 2018; 249: 226-33.

57. Colom X, Carrillo F, Nogués F, Garriga P. Structural analysis of photodegraded wood by means of FTIR spectroscopy. Polym Deg Stab. 2003; 80: 543-49. 
58. Hsu T-C, et al. Effect of dilute acid pretreatment of rice straw on structural properties and enzymatic hydrolysis. Bioresour technol. 2010; 101(13): 4907-4913.

59. Segal L, Creely JJ, Martin AE Jr, Conrad CM. An empirical method for estimating the degree of crystallinity of native cellulose using the X-ray diffractometer. Textile Res J. 1962; 29: 786-94.

60. Bi S, Peng L, Chen K, Zhu Z. Enhanced enzymatic saccharification of sugarcane bagasse pretreated by combining $\mathrm{O}_{2}$ and $\mathrm{NaOH}$. Bioresour Technol. 2016; 214: 692-99.

61. Ang TN, Ngoh GC, Chua ASM, Lee MG. Elucidation of the effect of ionic liquid pretreatment on rice husk via structural analyses. Biotechnol Biofuels. 2012; 5:67.

62. Dadi AP, Varanasi S, Schall CA. Enhancement of cellulose saccharification kinetics using an ionic liquid pretreatment step. Biotechnol Bioengineer. 2006; 95: 904-910.

63. Feng $\mathrm{L}$, Chen ZI. Research progress on dissolution and functional modification of cellulose in ionic liquids. J Mol Liq. 2008; 142: 1-5.

64. Shill K, Padmanabhan S, Xin Q, Prausnitz JM, Clark DS, Blanch HW. Ionic liquid pretreatment of cellulosic biomass: enzymatic hydrolysis and ionic liquid recycle. Biotechnol Bioengineer. 2011; 108: 511-20.

65. Li Q, He YC, Xian M, Jun G, Xu X, Yang JM, Li LZ. Improving enzymatic hydrolysis of wheat straw using ionic liquid 1-ethyl-3-methyl imidazolium diethyl phosphate pretreatment. Bioresour Technol. 2009; 100(14): 3570-

66. Uju, Shoda Y, Nakamoto A, Goto M, Tokuhara W, Noritake Y, Katahira S, Ishida N, Nakashima K, Ogino $\mathrm{C}$, Kamiya N. Short time ionic liquids pretreatment on lignocellulosic biomass to enhance enzymatic saccharification. Bioresour Technol. 2012; 103: 446-52.

67. Sun FF, Zhao X, Hong J, Tang Y, Wang L, Sun H, Li X, Hu J. Industrially relevant hydrolyzability and fermentability of sugarcane bagasse improved effectively by glycerol organosolv pretreatment. Biotechnol Biofuels. 2016; 9: 59.

68. Zhang YH, Lynd LR. Toward an aggregated understanding of enzymatic hydrolysis of cellulose: Noncomplexed cellulase systems. Biotechnol Bioengineer, 2004; 88: 797-824.

69. Cao W, Sun C, Liu R, Yin R, Wu X. Comparison of the effects of five pretreatment methods on enhancing the enzymatic digestibility and ethanol production from sweet sorghum bagasse. Bioresour Technol. 2012; 111: 215-221.

70. Corrales RCNR, Mendes FMT, Perrone CC, Anna CS, de Souza W, Abud Y, da Silva Bon EP, FerreiraLeitão V. Structural evaluation of sugar cane bagasse steam pretreated in the presence of $\mathrm{CO}_{2}$ and $\mathrm{SO}_{2}$. Biotechnol Biofuels. 2012; 5:36.

71. Segel IH. Biochemical Calculations: How to Solve Mathematic Problem in General Biochemistry, second ed., John Wiley and Sons, California, 1976.

72. Shuler ML, Kargi F. Bioprocess Engineering: Basic Concepts, second ed., Prentice Hall, New Jersey, 1992. 
73. Santos VTO, Esteves PJ, Milagres AMF, Carvalho W. Characterization of commercial cellulases and their use in the saccharification of a sugarcane bagasse sample pretreated with dilute sulfuric acid. Journal of Industrial Microbiol Biotechnol. 2011;38: 1089-1098.

\section{Figures}

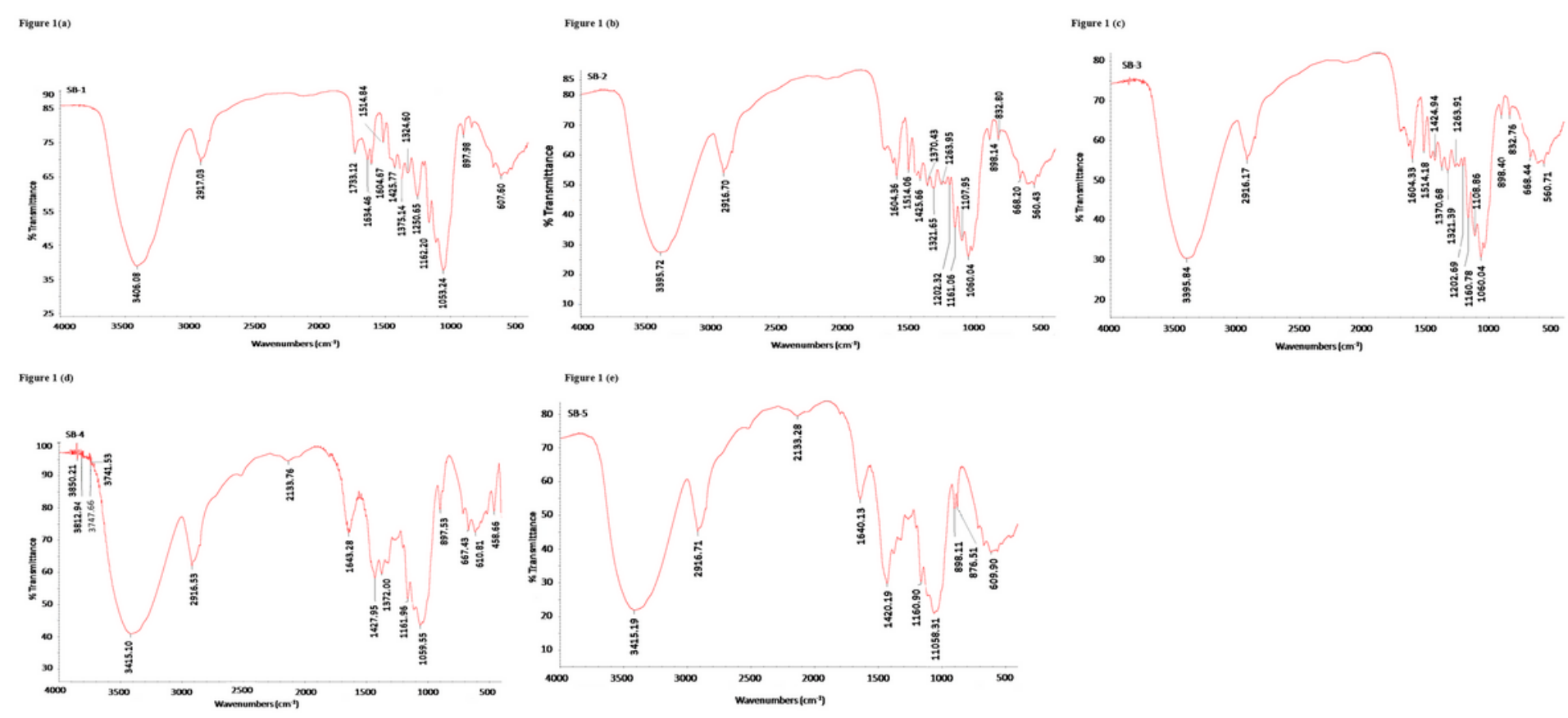

Figure 2

Fourier transform infrared (FTIR) spectra of un-treated, acid and alkali pretreated sugarcane bagasse (SB). (a) Untreated sugarcane bagasse, (b) $5 \%$ sulfuric acid pretreated bagasse at $121 \mathrm{C}$ for $60 \mathrm{~min}$, (c) $10 \%$ sulfuric acid pretreated bagasse at $121^{\circ} \mathrm{C}$ for $60 \mathrm{~min}$ (d) $5 \%$ Sodium hydroxide pretreated bagasse at $121^{\circ} \mathrm{C}$ for $60 \mathrm{~min}$ (e) $10 \%$ sodium hydroxide pretreated bagasse at $121^{\circ} \mathrm{C}$ for $60 \mathrm{~min}$. Crl, crystallinity index; SB, sugarcane bagasse; XRD, X-ray diffraction. 
Figure 2(a)

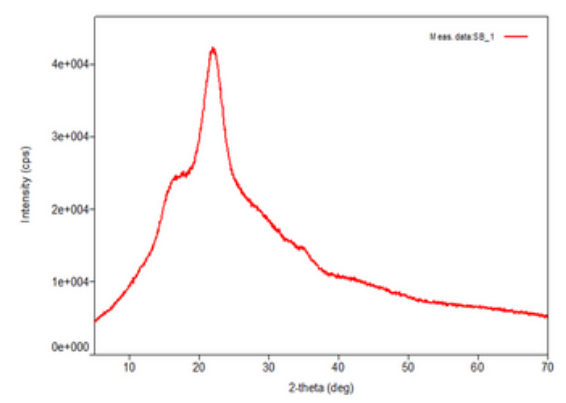

Figure 2 (d)

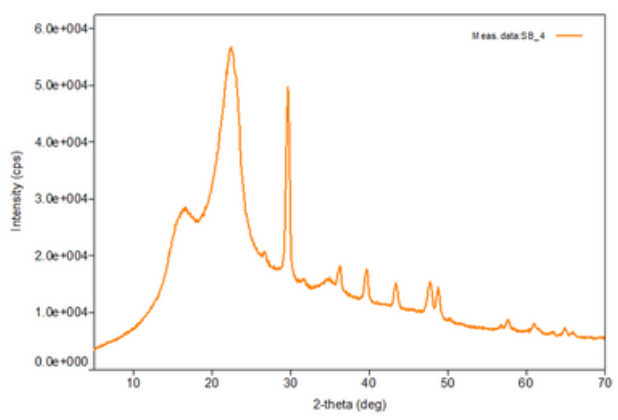

Figure 2 (b)

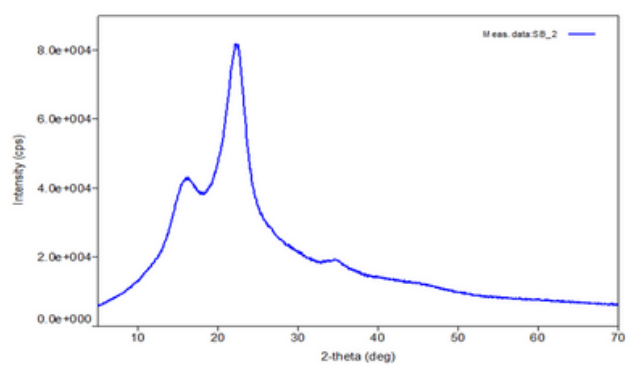

Figure $2(e)$

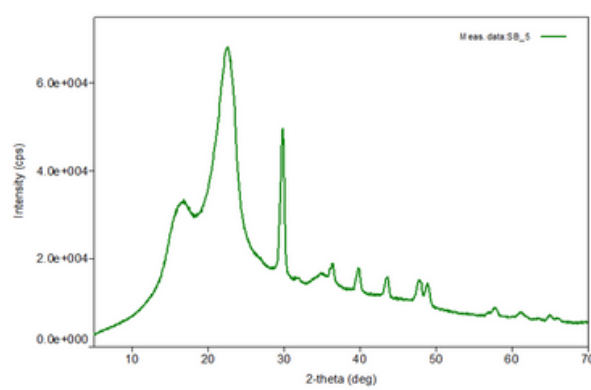

Figare 2 (c)

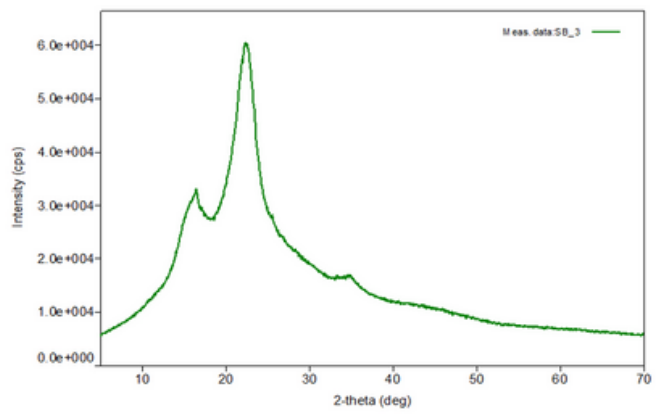

\section{Figure 3}

X-ray diffraction (XRD) pattern of native, acid and alkali pretreated sugarcane bagasse (SB). The crystallinity index (Crl) was found to be increased in cellulignin and $\mathrm{NaOH}$ pretreated bagasse. Enzymatic hydrolyzed SB showed the Crl value of cellulignin and $\mathrm{NaOH}$ treated bagasse. (a) Untreated sugarcane bagasse, (b) $5 \%$ sulfuric acid pretreated bagasse at $121^{\circ} \mathrm{C}$ for $60 \mathrm{~min}$, (c) $10 \%$ sulfuric acid pretreated bagasse at $121^{\circ} \mathrm{C}$ for $60 \mathrm{~min}$ (d) $5 \%$ Sodium hydroxide pretreated bagasse at $121^{\circ} \mathrm{C}$ for $60 \mathrm{~min}$ (e) $10 \%$ sodium hydroxide pretreated bagasse at $121^{\circ} \mathrm{C}$ for $60 \mathrm{~min}$. Crl, crystallinity index; SB, sugarcane bagasse; XRD, X-ray diffraction. 

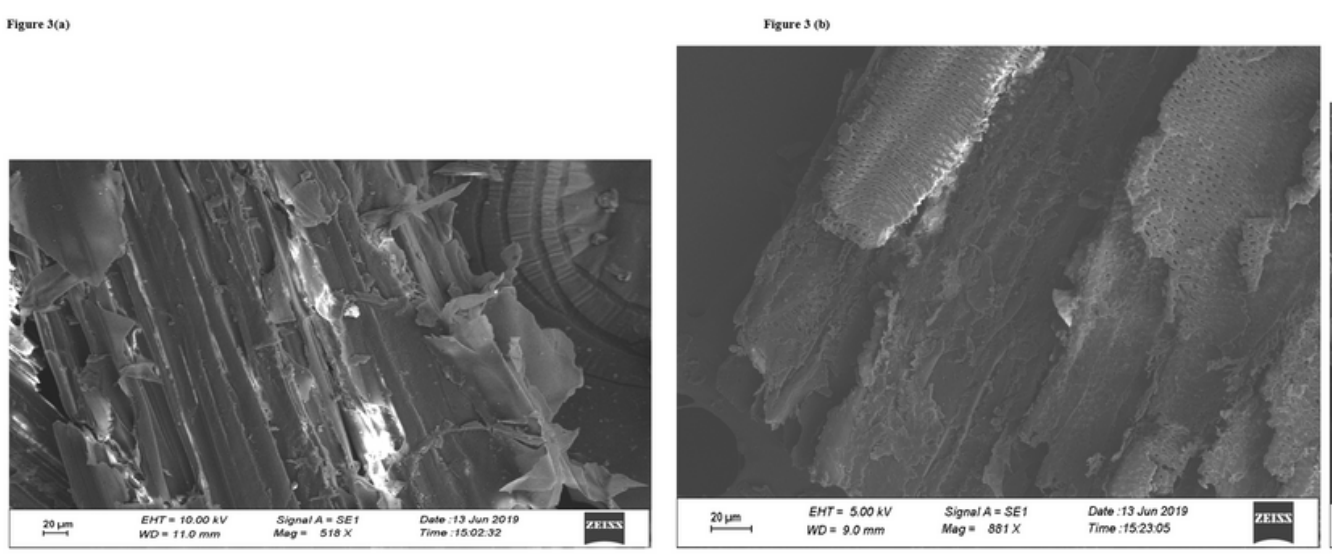

Figure 3 (c)
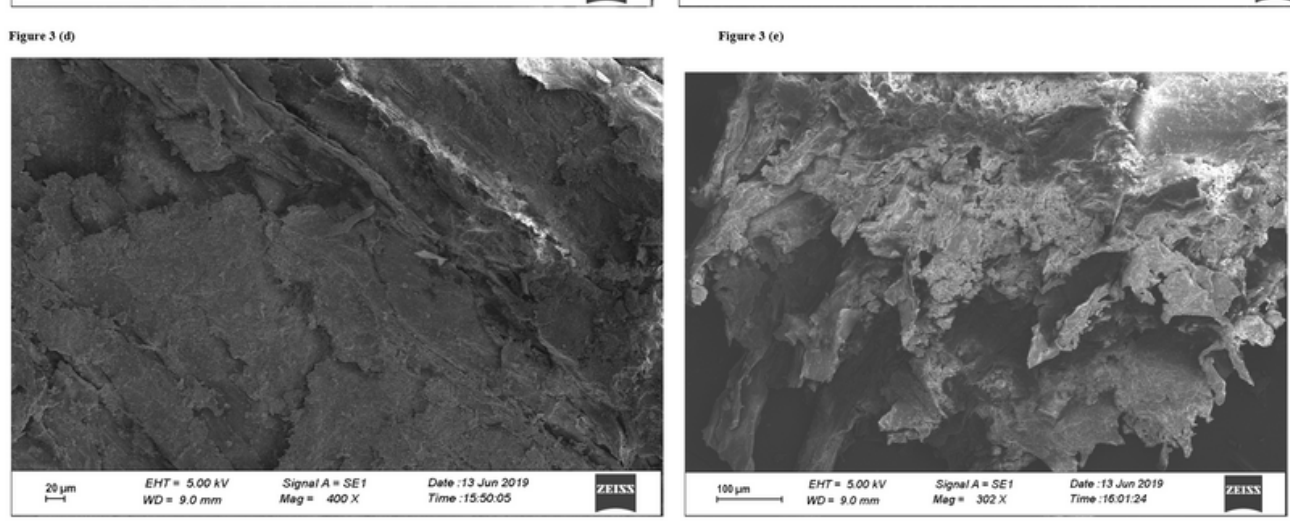

\section{Figure 5}

Scanning electron microscopic (SEM) analysis of sugarcane bagasse (SB). Showing surface image of (SB-1) natural, (SB-2) $10 \%$ sulfuric acid pretreated at $121^{\circ} \mathrm{C}$ for $30 \mathrm{~min}$, (SB-3) $10 \%$ sulfuric acid pretreated at $121^{\circ} \mathrm{C}$ for $60 \mathrm{~min}$ (SB-4) $10 \%$ sodium hydroxide pretreated at $121^{\circ} \mathrm{C}$ for $30 \mathrm{~min}$, and (SB-4) $10 \%$ sodium hydroxide pretreated at $121^{\circ} \mathrm{C}$ for 60 min. SB:- Sugarcane Bagasse; SEM:- Scanning Electron Microscopy.
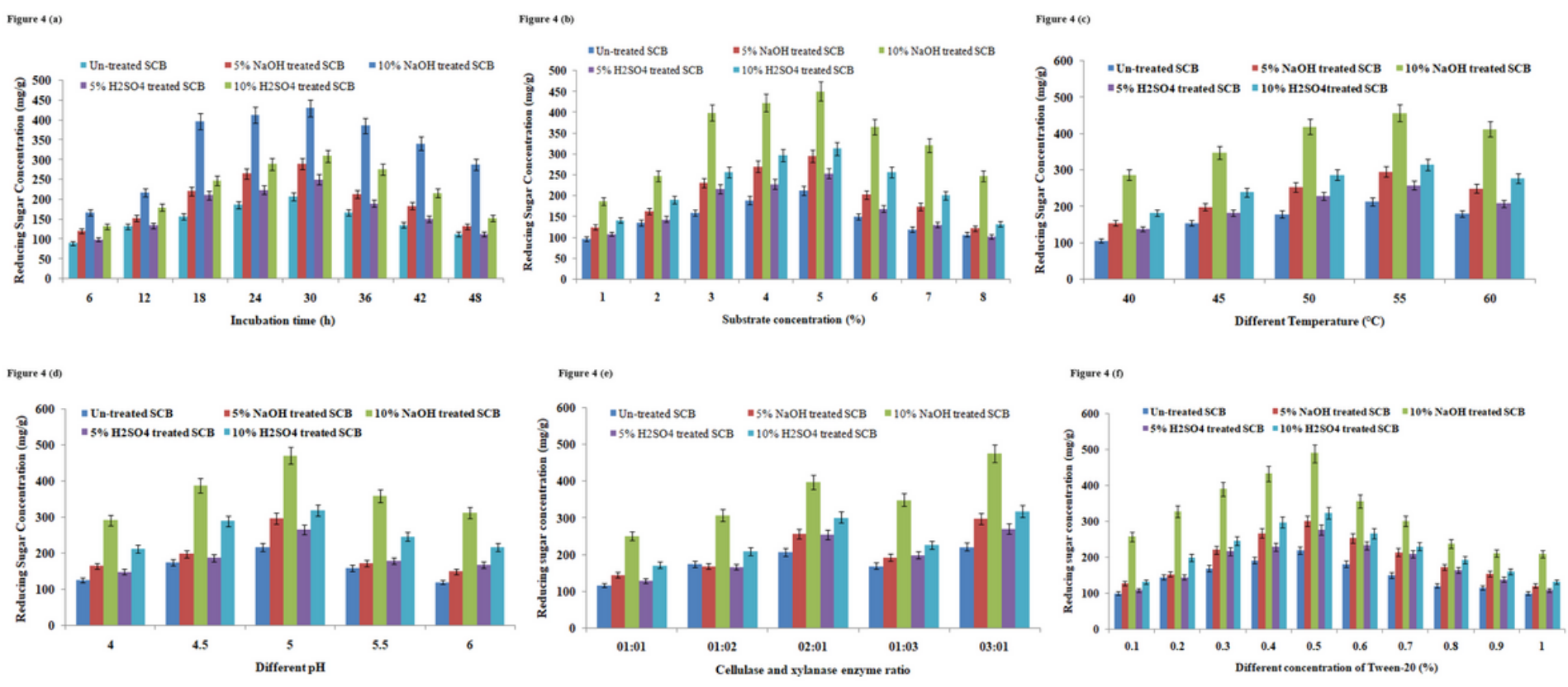

Figure 8 
Reducing sugars yield of un-treated, acid ( 5 and $10 \% \mathrm{H} 2 \mathrm{SO} 4$ at $121^{\circ} \mathrm{C}$ for $60 \mathrm{~min}$ ) and alkali (5 and $10 \%$ $\mathrm{NaOH}$ at $121^{\circ} \mathrm{C}$ for $60 \mathrm{~min}$ ) pretreated SCB (Sugarcane bagasse) after enzymatic hydrolysis. The hydrolysis was carried out using Pseudomonas sp. CVB-10 and Bacillus paramycoides T4 enzymes (cellulase and xylanase) with an enzyme load of $25 \mathrm{FPU} / \mathrm{g}$. (a) The effect of different time incubation on enzymatic hydrolysis at $55^{\circ} \mathrm{C}, \mathrm{pH} 5.0$ and $2 \%$ substrate concentration. (b) The effect of different substrate concentration on enzymatic hydrolysis at $55^{\circ} \mathrm{C}, \mathrm{pH} 5.0$ for $30 \mathrm{~h}$ (c) The effect of different temperature on enzymatic hydrolysis at $\mathrm{pH} 5.0,5 \%$ substrate concentration for $30 \mathrm{~h}$ (d) The effect of different $\mathrm{pH}$ on enzymatic hydrolysis at $55^{\circ} \mathrm{C}, 5 \%$ substrate concentration for $30 \mathrm{~h}(\mathrm{e})$ The effect of different enzyme ratio on enzymatic hydrolysis at $55^{\circ} \mathrm{C}, \mathrm{pH} 5.0$, and $5 \%$ substrate concentration for $30 \mathrm{~h}$ (f) The effect of different concentration of Tween-20 on enzymatic hydrolysis at $55^{\circ} \mathrm{C}, \mathrm{pH} 5.0,5 \%$ substrate concentration and 3:1 enzymes concentration for $30 \mathrm{~h}$ 